\title{
Learning Gender-based Attitudes in The Bahamas
}

\author{
William J. Fielding \\ Virginia C. F. Ballance \\ University of The Bahamas
}

\section{Abstract}

Gender-based violence continues to be a source of concern in The Bahamas. Structural inequality between the sexes is present in the law and cultural attitudes can work to circumscribe the expectations of women. Such attitudes are reinforced through messages from various sources. This paper presents the results from an Internet-based survey of 1,279 participants to examine how Bahamian citizens learn their attitudes towards women. The most important influence on Bahamians was the participant's mother. She, in turn, was influenced by the messages she received from faith-based sources. Official governmental sources of information and the opinions of politicians and school teachers appeared to be less influential. This disparity suggests that within The Bahamas, changes in attitudes towards women will require a more enlightened message to be taught and reinforced by faith-based organizations.

\section{Introduction}

Historically, women in the Caribbean, as elsewhere, have been considered vulnerable members of society (Blank, 2013). In today's society, there is continuing worldwide concern for the safety of women, and in particular, its relation to gender-based violence. For example, in Pakistan, Saeed Ali et al. (2017) point out that "patriarchal gender norms and values reinforce and sustain the low status of girls and women in society and increase the likelihood that boys and men will perpetrate violence against girls" (p. 1).

The United Nations has encouraged nations to end all forms of discrimination against women through its Convention on the Elimination of all forms of Discrimination Against Women (CEDAW) adopted in 1979, to which The Bahamas is a signatory. Despite such initiatives, in The Bahamas women in particular are at risk of experiencing violence within their own homes (Plumridge \& Fielding, 2009). The link between violence in the home and gender stereotypes (Graham-Bermann \& Brescoll, 2000) is of concern.

The constitution of the Bahamas institutionalizes inequality between males and females; for example, Bahamian men and women are not equally able to pass on their nationality to their children. Two referenda on gender equality at the start of the 21st century (one in 2002 and the other in 2016, Coleby, 2016) aimed at addressing this gender-based inequality both failed at the ballot box (Boyd, 2016). This may point to a deeply ingrained attitude in the country with regard to equality of men and women under the law as well as "structural violence" - as Bethell-Bennett (2016) states, "even boys brought up in single-motherheaded households where the mother is educated are socially engineered to think that men run things" (p. 56). The gender gap is reflected in the disparity in the wages paid to men and women (despite women being better educated, Fielding \& Gibson, 2015) and women holding ever more of the senior positions in the country, with the exception 
of the House of Assembly where they remain a minority (Turnquest, 2018a; Organization for Economic Cooperation and Development, 2019).

Gender-based violence has been the subject of global and regional research (QuaminaAiyejina \& Brathwaite, 2005) that has examined the phenomenon from many angles, including the determination of factors which heighten the risk of its occurrence (Abramsky et al., 2011). Physical violence between men and women is an as aspect of domestic violence (for example, Bahamas Crisis Centre, n.d.) and included in screening tools on domestic violence such as that in Sherin, Sinacore, Li, Zitter, and Shakil (1998). While no official statistics are available on the prevalence of domestic violence in The Bahamas, studies point to there being domestic violence in $20-30 \%$ of households (Fielding, Ballance, \& Strachan, 2016); these figures place The Bahamas in the range seen elsewhere (WHO, 2017). National awareness of the abusive treatment of women in society has led to a strategic plan concerning gender-based violence (Bahamas National Task Force for Genderbased Violence, 2015) and Curry (2016) gives an overview of gender-based violence in The Bahamas. The national concern with regard to gender equality is shared by international groups (United Nation Human Rights, Office of the High Commissioner, 2017).

The Bahamas has a higher prevalence of rape than elsewhere in the Caribbean (Sutton \& Ruprah, 2017) and North America (Statista, 2019), which is a cause of concern. It is claimed that child sexual abuse in general is underreported in The Bahamas (Aranha, 2016), and this may also be the case with rape. Attempts to outlaw marital rape have proved to be contentious, with both politicians and the Bahamian Christian Council being cautious to criminalize it
(Turnquest, 2018b); an analysis of the debate concerning martial rape was given by Benjamin and LeGrand (2012). Some individual religious figures have condemned marital rape (Jones, 2018), while others have effectively justified it (Cleare, 2017). In 2017, the Ministry of Social Services was of the view marital rape was a private matter (Smith, 2017), and martial rape should not be outlawed. This attitude ignores the fact that parental conflict can negatively impact children in the home (Johnson, 2016).

It should be noted that physical violence is common in Bahamian homes, as it is commonly used to discipline children (Fielding et al., 2016). Violence is more common in Bahamian homes than those in the United States, and the person who is most likely to discipline the children is the mother (Fielding, Risley-Curtiss, \& Cronin, 2015). This violence can lead to abuse of the children and help to perpetuate the cycle of violence (Brennen et al, 2010). Further, the use of corporal punishment in schools can result in children moving from one violent environment to another (Fielding et al., 2016). Therefore, violence is normative for many children.

The Bahamas has a higher tolerance than other territories in the Caribbean for accepting that a man can discipline his wife for her behaviour (Sutton \& Ruprah, 2017). Nicolls et al. (2014) demonstrated that by the time they reached high school, students had already learned that the man should be the head of the household, a woman must submit to her husband, and that a woman's place was in the home. Further, that study indicates that young, yet-to-be partnered women had already learned to expect that a future intimate partner could express love for them by hitting. The hitting of an intimate partner was admitted by a Member of Parliament (MP) in the House of Assembly, to the amusement of its members, 
who appeared to condone the act (Smith 2014, Turnquest, 2014a). A female MP reminded women that they can expect to be disciplined if they do not do as their husband instructs ("MICAL MP suggests it's okay for a man to beat his wife", 2018). This seems consistent with the idea that in Bahamian society women are "soft" and men "hard" (Bethel, 2003). So, despite a legal framework which aims to protect society from violence, as seen in Domestic Violence (Protection Orders) Act of 2007, the behaviours related by lawmakers appear to suggest a tension between cultural norms and the law.

Schools and homes have been found to have important influences propagating gender stereotypes (Naffziger \& Naffziger, 1974) as well as religious affiliation (Seguino \& Lovinsky, 2009). Religious socialization has been linked with various behaviours and these are in turn influenced by parents' religiosity (Taggart, Gottfredson, Powell, Ennett, \& Chatters, 2019). Studies on masculinities in The Bahamas, indicate that being head of the household is a male expectation and men are expected to dominate their woman (Strachan, 2013). This attitude towards domination has the potential to lead to conflict and violence in the home if the man expects his wishes to be met - because he is in charge. Research in the United States has shown that male dominance is associated with the risk of violence towards women (Karakurt \& Cumbie, 2012). In the Bahamian context, where Christianity is the dominant religion, these expectations can be reinforced by ministers of religion, depending upon their interpretation of the Bible; for example, the household codes in the letters of Saint Paul are said to support the idea that rape cannot occur inside marriage (Cleare, 2018). Further, given that the majority of teachers in The Bahamas are female, women who emerge from male-dominated households, or households with domestic violence (Johnson, 2016), may unwittingly pass on to their pupils expectations of potentially violent male household dominance as normative because this reflects their home reality.

Therefore, this makes an understanding of the pathway by which stereotypes are learned important if women are to be protected from possible violence associated with gender-based attitudes. The fact that young children have learned dismissive attitudes toward women invites us to ask the question who is teaching them these opinions? While we can conjecture that they are learning them from their family or school, or religious communities, there appears to have been no attempt to identify the mechanism through which these views are learned. Once there is an understanding of how the learning might occur, it may be possible to construct a communication strategy which could challenge these discriminatory messages.

The purpose of this investigation was to obtain preliminary information as to how residents of The Bahamas learn gender stereotypes; in particular, from whom and at what age were attitudes first formed/learned. Once the sources of information have been identified, it may become possible to devise means by which messages which support the status quo can be interrupted. As such it was aimed to identify the more important information sources or influences of respondents, and when they formed their opinion of gender stereotypes.

\section{Methodology}

An internet questionnaire was devised. It consisted of demographic questions, including two to allow any survey participants who were not part of the target group (defined as Bahamian citizens 
ordinarily living in The Bahamas) to be omitted during the cleaning of the data. Questions focused on acts of violence in the home of the respondents when they were growing up, as well as their sources of news in general as well as information relating to women's issues. Questions regarding attitudes towards women were drawn from Nicolls et al. (2014) and the Latin American Public Opinion Project survey (Vanderbilt University, 2014). With regard to attitudes and how much respondents paid attention to various information sources, a 10-point scale was used, from zero to nine, with zero indicating complete disagreement or not an information source. Students from a research methods class invited members in their social media and instant messaging groups to complete the survey, and these invitees were also asked to share the study link with their contacts so as to generate a snowball sample. The projected sample size was 750 participants. The data were collected during the Fall semester of 2018. The project was approved by the Institutional Review Board of University of The Bahamas. Those who entered the survey had to give specific consent to participate before they could view the survey questions.

In reporting the results, the term "the church" is used to indicate faith-based groups. However, it is recognized that the various denominations have different nuances in their teachings of the relationships between men and women and their role in the home/family unit. Of the 899 respondents who indicated the name of their faith-based community, only one indicated being associated with a faith community which was not biblically based.

\section{Results}

A total of 1,406 starts were logged on the survey. Thirteen persons who accessed the survey link declined to participate. After cleaning the data, there were 1,279 respondents who were Bahamian citizens ordinarily resident in The Bahamas. Respondents did not necessarily answer all the questions so this number gives the maximum number of respondents. Of 1,276 respondents $28.1 \%$ were male, $71.7 \%$ were female and the remainder other. The modal educational attainment was incomplete university degree $(31.5 \%$ of 1,184 responses), which probably reflects the results of the snowball sample originating from a university student group. The modal age group was 18-24 (42\%). When growing up, the family structure was most likely to include a female presence, as indicated by Table 1. Most of the respondents $(89.6 \%$ of 1,009 participants) had had an intimate partner at some period of their lives.

Table 1

Prevalence of persons in participant households

\begin{tabular}{ll}
\hline Household member & $\%$ \\
\hline Mother figure & 82.3 \\
Father figure & 48.6 \\
Siblings & 43.8 \\
Grandmother & 25 \\
Grandfather & 10.2 \\
Female guardian & 4.2 \\
Male guardian & 1.8 \\
Other relations & 8.4 \\
\hline
\end{tabular}

Note: Multiple were responses allowed. Mother figure includes mothers, step-mothers, the father's live-in girlfriend, female guardian etc. Similarly, father figure includes fathers, stepfathers, the mother's live-in boyfriend, male guardian etc.

Only $1.4 \%$ of 1,277 participants had never been disciplined in any way while growing up at home, $58.9 \%$ had been hit with an object, $24.7 \%$ by the hand, and $15 \%$ had been disciplined, but not by hitting. Given that hitting a child with an object puts that child at higher risk of being abused, ${ }^{1}$ the

\footnotetext{
${ }^{1}$ According to Brennen et al. (2010), in The
} 
data show that male respondents were at greater risk than female respondents of being abused when disciplined. The Odds Ratio (OR) of males compared to females being hit with an object rather than any other means of being disciplined was $\mathrm{OR}=1.33$, 95\% CL $=[1.03-1.71], N=1,272$. Of 1,277 respondents, $19.7 \%$ remembered seeing their parental figures hitting each other; this percentage was similar for both male and female respondents. These behaviours were also positively correlated, in that respondents who saw their parents hit each other were more likely to have been disciplined with an object $(72.1 \%$ of 251 respondents) than those who did not see their parents hit each other $(55.6 \%$ of 1,024 , $\left.\chi^{2}=24.5, d f=3, N=1275, p<.001\right)$.

Most respondents attended a religious faith community ( $78 \%$ of 1,275 responses). Of 955 respondents who attended a faith-based community, $39.7 \%$ had attended a church meeting/service in the last seven days, $26.2 \%$ in the last four weeks, and the remainder longer than four weeks ago.

Given that this was an Internet-based survey, the fact that $95.5 \%$ (of 1,010) respondents had a social media account might be expected and $89.6 \%$ had used their account on the day they completed the survey.

The attitudes of both the males and female respondents towards gender roles show similar rank orders (see Table 2). There was more agreement that a man/husband should be the head of the household, and less agreement that a woman's place is in the home. The majority of respondents $(91.5 \%$ of 848 respondents) totally disagreed that a man shows his love to his intimate partner by hitting her. While respondents were not always sure when they learnt their attitude towards women, the median ages indicated that, in most cases, the attitudes were typically formed no later than their early teenage years.

While most respondents had learned from faith-based teachings that a man is a head of the house and that a woman should submit to their husband, most respondents reported that the family was the place they were most likely to have learnt that the place of women was in the home (Table 3). For none of these attitudes, was the school singled out as an important place where the attitude was learned.

While there was little difference between the attitudes of male and female respondents to the man being the head of the household (Mann-Witney $\mathrm{U}=83252, \mathrm{Z}=-1.604, p=$ .11), males and females differed significantly in their attitudes to "a woman's place being in the home", (Mann-Witney U $=76163, \mathrm{Z}=-2.213, p=.027$ ), and that "a man shows his love to his intimate partner by hitting her", (Mann-Witney $\mathrm{U}=66517$, Z $=-3.208, p=.001)$. Attending a religious/faith community is associated with differences in attitudes towards agreeing that "a woman/wife should submit to her intimate partner/husband" (Witney U = $56485, \mathrm{Z}=-3.659, p<.001)$, agreeing that "a man shows his love to his intimate partner by hitting her" (Witney $\mathrm{U}=56644, \mathrm{Z}$ $=-1.981, p=.048)$, agreeing that "a man/husband should be the head of the household" (Witney U = 58844, Z = -3.672, $p<.001$ ), but not that "a woman's place in in the home" (Witney $U=63563, Z=-.590$, $p=.56)$. 
Table 2

Attitudes towards gender and mean age at which they were learnt.

(Scale: $0=$ not at all, $9=$ a great deal).

\begin{tabular}{|c|c|c|c|c|c|c|c|c|c|c|}
\hline \multirow[b]{3}{*}{ Do you agree that a: } & \multicolumn{4}{|c|}{ Attitude } & \multicolumn{6}{|c|}{ Age (years) when learnt } \\
\hline & \multicolumn{2}{|c|}{ Males } & \multicolumn{2}{|c|}{ Females } & \multicolumn{3}{|c|}{ Males } & \multicolumn{3}{|c|}{ Females } \\
\hline & $M$ & SEM & $M$ & SEM & $M d n$ & $Q_{1}$ & $Q_{3}$ & Mdn & $Q_{1}$ & $Q_{3}$ \\
\hline $\begin{array}{l}\text { Man/husband should } \\
\text { be the head of the } \\
\text { household? }\end{array}$ & 7.5 & 0.15 & 7.3 & 0.09 & 10 & 7 & 13 & 11 & 8 & 14 \\
\hline $\begin{array}{l}\text { A woman/wife must } \\
\text { submit to her intimate } \\
\text { partner/ husband? }\end{array}$ & 5.7 & 0.18 & 5 & 0.12 & 11 & 8 & 15 & 13 & 10 & 16 \\
\hline $\begin{array}{c}\text { Woman's/wife's place } \\
\text { is at home? }\end{array}$ & 2.8 & 0.17 & 2.5 & 0.11 & 11 & 8 & 15 & 12 & 9 & 15 \\
\hline $\begin{array}{c}\text { Man shows his love to } \\
\text { his intimate partner by } \\
\text { hitting her? }\end{array}$ & 0.4 & 0.10 & 0.2 & 0.04 & 9 & 7 & 13 & 10 & 7 & 13 \\
\hline
\end{tabular}

Note: Some respondents rather than giving an age indicated that they learnt the attitude at "an early age". These responses were coded as seven years. Likewise, those who responded "early teens" were coded 13 and "teenage years" coded 16 years.

Table 3

Percentage of respondents indicating where attitude had been learnt. Only where responses from males and females differed are the results disaggregated.

\begin{tabular}{lcccc}
\hline $\begin{array}{l}\text { Place attitude } \\
\text { learned } \\
\text { (themed) }\end{array}$ & $\begin{array}{c}\text { A man should be the head } \\
\text { of the household } \\
\text { Overall }\end{array}$ & $\begin{array}{c}\text { Women's place is in } \\
\text { the home } \\
\text { Overall }\end{array}$ & $\begin{array}{c}\text { Woman should submit to her } \\
\text { intimate partner } \\
\text { Male }\end{array}$ & Female \\
\hline Church & $48.6 \%$ & $19.1 \%$ & $44.2 \%$ & $50.9 \%$ \\
Family & $42.3 \%$ & $43.8 \%$ & $28.4 \%$ & $29.2 \%$ \\
Society & $4.3 \%$ & $16.3 \%$ & $15.8 \%$ & $7.3 \%$ \\
School & $1.7 \%$ & $3.9 \%$ & $0.5 \%$ & $2.4 \%$ \\
Other & $3.1 \%$ & $16.9 \%$ & $11.1 \%$ & $10.3 \%$ \\
\hline$n=$ & 843 & 698 & 190 & 507 \\
\hline
\end{tabular}

Of the respondents who participated in a religious/faith-based community, $92.7 \%(n=$ 671) were totally opposed to a man/husband hitting his intimate partner to show his love, compared with $87.9 \%(n=174)$ who did not participate in a faith-based community 
indicating that those who did not attend a religious/faith-based community were more likely to approve of this behaviour than those who did attend (test for a difference between two percentages, $p=.046)$.

Participants thought that the actions of a women which would justify the husband/ intimate partner hitting her were in selfdefense $(14.2 \%)$, during sex $(1.5 \%)$ and if she was disrespectful $(0.5 \%$, of 857 responses).

Mother figures (mothers or those filling that role in the life of the respondent) were the persons who were the most important voice to which respondents listened, both in general and with regard to attitudes toward women (Table 4). Intimate partners were the second most listened to voice with regard to attitudes towards women, and MPs the least important. The rank order of these sources for male and female respondents, although not identical, was similar (paired t-test, $p>$ $.05)$.

The extent to which participants paid attention to information sources, was often correlated with their attitudes towards gender roles. Therefore, to determine the influences of attitudes towards gender roles, a regression analysis involving 28 variables associated with attitudes towards women was done using a backward elimination approach. The variables which were retained were significant at the five percent level or less, are listed is Table 5. They can be viewed as falling into five groups, faith community influences, family influences, school influences, society influences, and violence in the home. When we compare the list of influences in Table 5 to the full list of influences in Table 4, we see that those influences which might considered "authority" or "relational" influences persist.
The direction of the coefficients in Table 5 is important. Unless otherwise noted, a positive coefficient indicates that increased attentiveness to, or the influence of a source results in increased support for an attitude. So, the higher the level of educational attainment, the less support there was for the attitude that a women's place is in the home. The less severe the discipline the respondent experienced as a child, the less likely they supported the attitude of a male being the head of the household. In the case of attending a faith community and having an intimate partner, a negative sign indicates that those who did not have a partner or did not attend a faith community were less supportive of an attitude. The larger the coefficient within a column, the more influential that variable. So the relatively large coefficient associated with the influence of ministers of religion indicates that their influence is more important than the level of discipline to which the respondent was subjected.

Faith community influences were consistently associated with reinforcing gender stereotypes, while both family and school were not consistent. Violence in the home also had a consistent association with gender attitudes. The factors associated with perceptions relating to biblically based issues (man as head of household, and a woman submitting to her husband) are generally different to that associated with a woman's place is in the home. Other that this source, Table 5 indicates that male and female respondents were often influenced by a differing array of sources. Only males were influenced by what MPs had to say, and this may influence may arise from the fact that almost all MPs are male (34 out of 39 in 2019 [Wells, 2019]). 
Table 4

Sources of information/influence, ordered by mean, on the participant.

(Scale: $0=$ not at all, $9=$ a great deal).

\begin{tabular}{|c|c|c|c|}
\hline In general: & $M$ & SEM & $n$ \\
\hline Do/did you pay attention to what your female parental figure says/said? & 7.3 & 0.07 & 1,007 \\
\hline $\begin{array}{l}\text { Are/were you influenced by your female parental figure when she } \\
\text { speaks/spoke on attitudes toward women? }\end{array}$ & 6.8 & 0.08 & 1,003 \\
\hline When at school, did you pay attention to what your school teachers said? & 6.8 & 0.07 & 1,008 \\
\hline Do/did you pay attention to what your intimate partner says/said? & 6.4 & 0.08 & 993 \\
\hline Do/did you pay attention to what your male parental figure says/said? & 6.1 & 0.09 & 1,000 \\
\hline $\begin{array}{l}\text { Do/did you pay attention to what your intimate partner says/said on attitudes } \\
\text { towards women? }\end{array}$ & 6.1 & 0.09 & 996 \\
\hline $\begin{array}{l}\text { Are/were you influenced by your male parental figure when he speaks/spoke } \\
\text { on attitudes toward women? }\end{array}$ & 5.2 & 0.10 & 1,004 \\
\hline $\begin{array}{l}\text { Were you influenced by your school teachers when they spoke on attitudes } \\
\text { toward women? }\end{array}$ & 5.1 & 0.09 & 1,002 \\
\hline Do/did you pay attention to what your school peers say/said? & 4.6 & 0.08 & 1,005 \\
\hline Do you pay attention to what minsters of religion say? & 4 & 0.10 & 989 \\
\hline $\begin{array}{l}\text { Are/were you influenced by what your school peers said on attitudes toward } \\
\text { women? }\end{array}$ & 3.9 & 0.08 & 997 \\
\hline Do/did you pay attention to what your university/college peers say/said? & 3.9 & 0.09 & 977 \\
\hline $\begin{array}{l}\text { Outside of General Election campaigns, do you pay attention to what } \\
\text { Members of Parliament say? }\end{array}$ & 3.9 & 0.09 & 1,000 \\
\hline $\begin{array}{l}\text { Do/did you pay attention to what your university/college peers say/said on } \\
\text { attitudes towards women? }\end{array}$ & 3.7 & 0.09 & 972 \\
\hline $\begin{array}{l}\text { Are you influenced by Ministers of religion when they speak on attitudes } \\
\text { toward women? }\end{array}$ & 3.4 & 0.10 & 979 \\
\hline $\begin{array}{l}\text { Are you influenced by what you hear on the radio concerning attitudes } \\
\text { towards women? }\end{array}$ & 2.9 & 0.04 & 975 \\
\hline $\begin{array}{l}\text { Are you influenced by what you see/hear on music videos or similar } \\
\text { attitudes towards women? }\end{array}$ & 2.7 & 0.04 & 974 \\
\hline $\begin{array}{l}\text { Are you influenced by what you see on TV concerning attitudes towards } \\
\text { women? }\end{array}$ & 2.6 & 0.04 & 975 \\
\hline See/hear elsewhere on the Internet on attitudes towards women? & 2.5 & 0.04 & 974 \\
\hline $\begin{array}{l}\text { Are you influenced by Members of Parliament when they speak on attitudes } \\
\text { toward women? }\end{array}$ & 2.4 & 0.09 & 965 \\
\hline
\end{tabular}


Table 5

Standardized regression coefficients, of variables which were significantly related $(p<.05)$ to an attitude.

\begin{tabular}{|c|c|c|c|c|c|c|}
\hline & \multicolumn{2}{|c|}{$\begin{array}{l}\text { Agree that a } \\
\text { man/husband should be } \\
\text { the head of the } \\
\text { household }\end{array}$} & \multicolumn{2}{|c|}{$\begin{array}{c}\text { Agree that a } \\
\text { woman/wife must } \\
\text { submit to her intimate } \\
\text { partner/husband }\end{array}$} & \multicolumn{2}{|c|}{$\begin{array}{c}\text { Agree that a } \\
\text { woman's/wife's } \\
\text { place is at home }\end{array}$} \\
\hline & Male & Female & Male & Female & Male & Female \\
\hline Attentive to what minister of religion say & 0.29 & 0.12 & 0.37 & 0.10 & & \\
\hline Attend a religious/faith community & & -0.13 & & -0.09 & & \\
\hline $\begin{array}{l}\text { Attentive to what your male parental } \\
\text { figure says/said? }\end{array}$ & 0.24 & & & & & \\
\hline $\begin{array}{l}\text { Attentive to what your male parental } \\
\text { figure says/said on women }\end{array}$ & & & 0.18 & & & \\
\hline $\begin{array}{l}\text { Attentive to what your female parental } \\
\text { figure says/said female parent figure }\end{array}$ & & & & & & -0.12 \\
\hline $\begin{array}{l}\text { Influenced by female parental figure on } \\
\text { women }\end{array}$ & & & -0.17 & & & 0.12 \\
\hline Ever had an intimate partner & & & & & -0.14 & \\
\hline $\begin{array}{l}\text { Attentive to what intimate partner } \\
\text { says/said on women }\end{array}$ & & & & 0.12 & & \\
\hline $\begin{array}{l}\text { Attentive to what your intimate partner } \\
\text { says }\end{array}$ & & 0.12 & & & & \\
\hline Level of educational attainment & & & -0.13 & & & \\
\hline $\begin{array}{l}\text { Attentive to what your school teachers } \\
\text { said? }\end{array}$ & & & 0.18 & 0.09 & & \\
\hline $\begin{array}{l}\text { Influenced by your school teachers on } \\
\text { attitudes toward women }\end{array}$ & & & -0.14 & 0.10 & & 0.15 \\
\hline $\begin{array}{l}\text { Influenced by MPs when they speak on } \\
\text { women }\end{array}$ & & & & & 0.28 & \\
\hline $\begin{array}{l}\text { When growing up, remember seeing } \\
\text { parents hitting each other in home }\end{array}$ & & & & & -0.16 & \\
\hline When growing up, disciplined at home & -0.13 & & -0.12 & -0.08 & & \\
\hline
\end{tabular}

A comparison of religious denominations, themed into Anglican, Roman Catholic, Methodist, Protestants (Baptists, nondenominational etc.), Seventh Day Adventists, which gave a minimum of 23 respondents in any group, indicated that there were significant differences $(p<.001)$ between these groups with regard to the attitude of a man being the head of the and that a woman must submit to her husband; the protestant group had the highest approval of both attitudes. There was no difference between the denominations in the attitudes about the place of the women in the home $(p=.31)$.

Outside of the specific sources of information listed in Table 6, the most important information source for both national and international news was social media. This suggests that social media is a 
commonly used medium for the transfer of information.

\begin{tabular}{lcc}
$\begin{array}{l}\text { Table } 6 \\
\text { Percentage of respondents obtaining news from } \\
\text { selected sources }\end{array}$ \\
\hline $\begin{array}{l}\text { National } \\
\text { news }\end{array}$ & $\begin{array}{c}\text { International } \\
\text { news }\end{array}$ \\
\hline $\begin{array}{l}\text { Social media } \\
\text { Internet news }\end{array}$ & 66.6 & 69.2 \\
services & 35.2 & 44.4 \\
Radio & 51.1 & 38.6 \\
TV foreign stations & 45.6 & 34.1 \\
TV local stations & 40 & 28.8 \\
Newspapers & 32.5 & 27.4 \\
Word of mouth & & 34.3 \\
\hline
\end{tabular}

\section{Discussion}

When considering the results of this study, it should be remembered that the method used to recruit participants, while resulting in a large number of respondents, cannot necessarily be expected to obtain a sample which reflects the wider population. Biases in the respondent group are evident in the fact that the modal group was aged 18-24 and had more than a high school education, which differs from the 2010 census data. However, it is hoped that the overall picture, which this sample provides, can be useful in providing a starting point regarding our understanding of attitudes towards women.

The results indicate that there was general agreement that a man should be the head of the household. There was less agreement with the statement that a woman should submit to her husband, but the overall attitude was one of agreement. Overall, respondents disagreed that the place of women was in the home. Few respondents supported the idea that a man expresses his love to his partner by hitting her. There were differences, usually in degree, between these attitudes for male versus female participants. These results are consistent with those reported by Bahamian school children on gender roles (Nicolls et al., 2014). As in Nicolls et al. (2014), our participants confirmed that attitudes towards women are formed at an early age. The finding that respondents remembered forming these attitudes typically before they were teenagers, is consistent with the idea that these attitudes are learned within the home, and primarily from mothers (Table 3 ). The learning path would appear to be that the home or a faith-based teaching group (Sunday school or similar) first introduces gender-based attitudes and these attitudes are then reinforced by pastors and others as the child grows-up. Although participants listened to their father figures, many participants did not have a father figure resident with them. Most had a mother figure at home; thereby, we may surmise, making the mother the more influential parental figure. This typical pattern demonstrates the matrifocal (mother and grand-mother) nature of the Bahamian society as noted by Bethel et al. (2012), among others. The importance of family or household members, in influencing attitudes towards women was highlighted by the themed responses as to where respondents first learned these attitudes. The results in Table 5 suggest that respondents tend to be more receptive to messages from their own sex. Witnessing parents hit each other in the home was linked to gender-role attitudes, which reminds us of the long-lasting effects of the exposure of children to violence (Tsavoussis, Stawicki, Stoicea, \& Papadimos, 2014). As such, violence in the home appears to play a role in forming attitudes which can in turn lead to violence. The pervasive influence of the home on school children has also been demonstrated in their academic performance (Collie- 
Patterson, 2008) and this influence is echoed here.

It should be noted, that although a child spends a great deal of time at school, school seemed to play a minor role in influencing respondents' attitudes. Even though civics is a part of the school curriculum, it may be taught at an age which is too late to have much influence of the attitudes of the children. Given the apparently mixed influences which schools have on attitudes examined in this study, the efficacy of methods of teaching of gender issues in schools could also be a source of future research.

Another important influence is faith-based sources. While young children may not pay much attention to what is said from the pulpit, they may be influenced by bible study. We can conjecture, that the influence of faith communities may be greater on adults, namely parents, who then teach what is heard in church and reinforce those messages with their children.

Although messages associated with faith communities reinforced or formed traditional gender roles, the identification of the respondents with a faith community, results in an even lower acceptance of the statement that a man shows his love to his partner by hitting her. This suggests that the moral compass provided by a faith community can help to protect women from physical harm. It also suggests that while a man is expected to be the head of the household and the woman should do as he says, there are limits to his behaviour toward her. The reasons offered by respondents as to when it might be acceptable for a man to hit his partner focused on safety (e.g. selfdefence), not on it being a consequence of the man being the head of the household.

Given that social media, the internet and the radio were the most common sources of news, it is noteworthy that media sources were reported as having limited influences on the attitudes of respondents. Notwithstanding this, it is clear that if messages are to be sent to support gender equality or promote respect for women, or convey information by which victims can support each other or seek support, these could be useful outlets to use because of their popularity of accessing information. However, it should be noted that the more influential sources are still essentially by direct communication, so the physical presence of the messenger would still appear to be important within the Bahamian community.

While the female parental figure was the most important source of information to which respondents paid attention, public information sources were given less attention. It was noticeable that MPs were less important information sources; this is despite the prominence given to their opinions in the media. This suggests that statements which emerge from politicians have limited influence on forming genderbased attitudes.

Of the gender-based attitudes, the view that a woman's place is in the home was more grounded in what might be considered societal influences, rather than home or church. Level of education influenced these attitudes, whereas this factor was not so important in influencing other attitudes. This may arise from education empowering women to make their own way in life, but still resulting in them making concessions to traditional gender-based norms with respect to male-female relationships.

\section{Conclusion}

Overall, the results from the study may mean that to effectively promote gender equality, faith-based groups need to be encouraged to rethink their teachings, which may actually 
promote gender inequality. A first step in this direction would be to research the nature of the messages from the Bahamian pulpit, which some claim promote gender inequality (Turnquest, 2014b). Gender biased messaging occurs in various faith groups such as in evangelical churches in the United States (Gallagher, 2004) and the Reformed Church in South Africa (Wood, 2019). Given the fact that in The Bahamas $34.9 \%$ of the population identified as Baptist (Bahamas Department of Statistics, 2012), many church goers may be exposed to views which may promote gender inequality. The influence of pastors raises questions with regard to their training, what education or training do those with the title "pastor" have relevant to this role? Despite claims that "most pastors" in The Bahamas are "educated, professional, intelligent" (Burrows, 2018), no statistics were

\section{References}

Abramsky, T., Watts, C. H., Garcia-Moreno, C., Devries, K., Kiss, L., Ellsberg, M., Jansen, H. A., \& Heise, L. (2011). What factors are associated with recent intimate partner violence? Findings from the WHO multicountry study on women's health and domestic violence. BMC Public Health, 11(109), 1-17. https://doi.org/10.1186/1471-2458-11-109

Aranha, S. B. (2016). Sexual abuse: The secret needing to be told. In W. J. Fielding, V. C. F. Ballance, \& I. G. Strachan (Eds.), Violence in The Bahamas (pp. 87-92). Nassau: University of The Bahamas.

Bahamas Crisis Centre. (n.d.) Domestic violence and abuse.

http://bahamascrisiscentre.org/index.php/getinformed/domestic-violence-abuse/

Bahamas Department of Statistics. (2012). Census of population and housing 2010. Nassau, Bahamas: Ministry of Finance. presented to support this view. It is estimated that worldwide "only 5\% [of pastoral leaders] are trained for pastoral ministry" (Richard, 2015). Given the importance of the teaching role of pastors in their congregations, it is necessary that pastors are adequately trained to fulfil it, rather how school teachers are trained. As such, Richard's estimate suggests that future research could also examine the qualifications of those who teach from the pulpit.

\section{Acknowledgements}

The authors are grateful to the students of the research methods class, SOCI200 of Fall 2018, for their assistance in the data collection. They are also grateful to Dr. Ian Strachan for reading an earlier draft of this paper and the helpful comments of the referees.

Bahamas National Task Force for Gender-based Violence. (2015). Strategic plan to address gender-based violence. Nassau, Bahamas: Ministry of Social Services and Community Development. Retrieved from https://www.bahamas.gov.bs/wps/wcm/connec t/3be7c3ad-862c-4c0f-ac44a2833552e00b/GBV+REPORT.Final.+August 2015.pdf?MOD=AJPERES

Benjamin, L., \& LeGrand, C. (2012). Sound and fury: Newspaper coverage of the marital rape debate in New Providence. International Journal of Bahamian Studies, 18, 16-35. https://doi.org/10.15362/ijbs.v18i0.164

Bethel, N. (2003). Engendering the Bahamas: A gendered examination of Bahamian nation making, or national identity and gender in the Bahamian context. College of The Bahamas Research Journal, 12, 72-84. https://doi.org/10.15362/ijbs.v12i0.54

Bethel, N., Minnis, J., \& Fielding, W. J. (2012). Knowing your ancestors: A survey of Bahamians' knowledge of their progenitor's 
names. International Journal of Bahamian

Studies, 18, 1-5. Retrieved from

http://journals.sfu.ca/cob/index.php/files/articl e/view/171/215

Bethell-Bennett, I. (2016). Enlightened sexism, structural violence or the failure of representative democracy? The 2016 Gender Equality Referendum. International Journal of Bahamian Studies, 22, 54-60.

https://doi.org/10.15362/ijbs.v22i0.272

Blank, S. (2013). An historical and contemporary overview of gendered Caribbean relations. Journal of Arts and Humanities, 2(4), 1-10. https://doi.org/10.18533/journal.v2i4.90

Boyd, L. (2016, June). Reflections on referendum 2016. Nassau Guardian. Retrieved from https://thenassauguardian.com/2016/06/24/refl ections-on-referendum-2016/

Brennen, S., Fielding, W. J., Carroll, M. C., McCants Miller, J. C., Adderley, L., \& Thompson, M. A. (2010). A preliminary investigation of the prevalence of corporal punishment of children and selected cooccurring behaviours in households on New Providence, The Bahamas. International Journal of Bahamian Studies, 16, 1-18. https://doi.org/10.15362/ijbs.v16i0.121

Burrows, D. (2018, January 4). The truth about pastors and their finances. Nassau Guardian. Retrieved from https://thenassauguardian.com/2018/01/04/thetruth-about-pastors-and-their-finances/

Cleare, A. (2018, March 2). A case against legalizing marital rape [Letter to the editor]. Nassau Guardian. Retrieved from https://thenassauguardian.com/2018/03/02/acase-against-legalizing-marital-rape/

Coleby, E. (2016, May 10). Speech on the four referendum bills delivered by former Bahamas Attorney General and Chief Justice. Retrieved from Bahamas Information Services website https://tinyurl.com/yxoprz7k

Collie-Patterson, J. M. (2008). The national average is D: Who is to blame? The College of The Bahamas Research Journal, 14, 28-37. https://doi.org/10.15362/ijbs.v14i0.102
Convention on the Elimination of all forms of Discrimination Against Women. (2017, March, 16). List of issues in relation to the sixth periodic report of the Bahamas. Geneva: Author. Retrieved from https://tbinternet.ohchr.org/_layouts/15/treatyb odyexternal/Download.aspx?symbolno=CEDA $\mathrm{W} \% 2 \mathrm{fC} \% 2 \mathrm{fBHS} \% 2 \mathrm{fCO} \% 2 \mathrm{f} 6 \&$ Lang=en

Curry, G. (2016). Overview of violence against women: The Commonwealth of The Bahamas. Retrieved from https://hr.un.org/sites/hr.un.org/files/Sabbatica 1\%20Report_VAW\%20in\%20the\%20Bahamas _GaynelCurry_June\%202016_0.pdf

Deveaux, L., \& Rolle, G. (2016). The Focus on Youth prevention and education research programme. International Journal of Bahamian Studies, 22, 91-98. https://doi.org/10.15362/ijbs.v22i0.276

Domestic Violence (Protection Orders) Act (2007). Government of The Bahamas. Retrieved from http://laws.bahamas.gov.bs/cms/images/LEGI SLATION/PRINCIPAL/2007/20070024/DomesticViolenceProtectionOrdersAct_ 1.pdf

Fielding, W. J., Ballance, V. C. F., \& Strachan, I. G. (Eds.). (2016). Violence in The Bahamas. Nassau: University of The Bahamas.

Fielding, W. J., Risley-Curtiss, C., \& Cronin, T. W. (2015). A cross-cultural comparison of interpersonal violence in the lives of college students from two colleges from The Bahamas and United States of America. International Journal of Bahamian Studies, 21(1), 38-56. https://doi.org/10.15362/ijbs.v21i1.230

Fielding, W., \& Gibson, J. (2015). Educational attainment of males and females in The Bahamas. https://doi.org/10.13140/RG.2.1.4490.1603

Gallagher S. K. (2004). The marginalization of evangelical feminism. Sociology of Religion, 65(3), 215-237. https://doi.org/10.2307/3712250

Graham-Bermann, S. A., \& Brescoll, V. (2000). Gender, power, and violence: Assessing the 
family stereotypes of the children of batterers. Journal of Family Psychology, 14(4), 600-612. https://doi.org/10.1037/0893-3200.14.4.600

Johnson, P. (2016). Violence in schools. In W. J. Fielding, V. C. F. Ballance, \& I. G. Strachan (Eds.), Violence in The Bahamas (pp. 113133). Nassau: University of The Bahamas.

Jones, R. (2018, January 22). Catholic archbishop: Marital rape a crime against human dignity. Nassau Guardian. Retrieved from https://thenassauguardian.com/2018/01/22/cat holic-archbishop-marital-rape-a-crime-againsthuman-dignity/

Karakurt, G., \& Cumbie, T. (2012). The relationship between egalitarianism, dominance, and violence in intimate relationships. Journal of Family Violence, 27(2):115-122. https://doi.org/10.1007/s10896-011-9408-y

MICAL MP suggests it's okay for a man to beat his wife. (2018, February, 2). Nassau Guardian. Retrieved from https://thenassauguardian.com/2018/02/08/mic al-mp-suggests-its-okay-for-a-man-to-beat-hiswife/

Nicolls, D., Russell-Smith, C., Dean-Patterson, S., Deveaux-Stuart, L. D., Gibson-Mobley, I., Williams, E. J, Pinder-Darling, A., \& Fielding, W. J. (2014). Attitudes of high school students regarding intimate relationships and gender norms in New Providence, The Bahamas. International Journal of Bahamian Studies, 20(1), 38-51. https://doi.org/ 10.15362/ijbs.v20i1.225

Organization for Economic Cooperation and Development. (2019). Gender, institutions and development database: Bahamas. Retrieved from https://oe.cd/ds/GIDDB2019

Quamina-Aiyejina, L., \& Brathwaite, J. A. (2005). Gender-based violence in the Commonwealth Caribbean: An annotated bibliography. Barbados: UNIFEM Caribbean Office. Retrieved from http://www.unifemcar.org/Photos/GENDERBASED\%20VIOLENCE\%20IN\%20THE\%20 COMMONWEALTH\%20CARIBBEAN.pdf
Richard, R. (2015). Training of pastors: A high priority for global ministry strategy. Lausanne Global Analysis, 5(4). Retrieved from https://www.lausanne.org/content/lga/201509/training-of-pastors

Saeed Ali, T., Karmaliani, R., Mcfarlane, J., Khuwaja, H., Somani, Y., Chirwa, E. D., \& Jewkes, R. (2017). Attitude towards gender roles and violence against women and girls (VAWG): Baseline findings from an RCT of 1752 youths in Pakistan. Global Health Action, 10(1), 1-9. https://doi.org/10.1080/16549716.2017.13424 54

Sherin, K. M., Sinacore, J. M., Li, X., Zitter, R. E., \& Shakil, A. (1998). HITS: A short domestic violence screening tool for use in a family practice setting. Family Medicine, 30(7), 508-512. Retrieved from http://www.stfm.org/fmhub/FULLPDF/JULY AUG98/cram1.pdf

Smith, K. (2014, March 5). Leslie Miller discussing beating his girlfriend [Video file]. Retrieved from https://www.youtube.com/watch?v=xSOalR3Z bqM

Smith, S. (2017, December 20). Rolle: Marital rape is a private issue. Nassau Guardian. Retrieved from https://thenassauguardian.com/2017/12/20/roll e-marital-rape-is-a-private-issue/

Statista. (2019). Number of reported forcible rape cases in the United States from 1990 to 2017. Retrieved from https://www.statista.com/statistics/191137/rep orted-forcible-rape-cases-in-the-usa-since1990/

Strachan, I. G. (2013). I's man: Manhood in the Bahamas [Video file]. Nassau, Bahamas: Marble Head Films. Retrieved from https://youtu.be/V0qPTvY7nYk

Sutton, H., \& Alvarez, L. (2016). How safe are Caribbean homes for women and children?: Attitudes toward intimate partner violence and corporal punishment. Washington, DC: InterAmerican Development Bank. https://doi.org/10.18235/0000546 
Sutton, H., \& Ruprah, I. (2017). Restoring paradise in the Caribbean. Combatting violence with numbers. Washington, DC: Inter-American Development Bank. Retrieved from https://publications.iadb.org/bitstream/handle/ 11319/8262/Restoring-Paradise-in-theCaribbean-Combatting-Violence-WithNumbers.PDF? sequence=1\&isAllowed $=\mathrm{y}$

The Family: People helping people program. (2018). Retrieved from https://www.bahamaslocal.com/showlisting/19 460/The_Family_People_Helping_People_Pro gram.html

Tsavoussis, A., Stawicki, S. P., Stoicea, N., \& Papadimos, T. J. (2014). Child-witnessed domestic violence and its adverse effects on brain development: A call for societal selfexamination and awareness. Frontiers in Public Health, 2, 178. https://doi.org/10.3389/fpubh.2014.00178

Turnquest, A. (2014a, March). Crisis Centre speaks out over lack of rebuke for Miller. The Tribune. Retrieved from http://www.tribune242.com/news/2014/mar/07 /crisis-centre-speaks-out-over-lack-rebukemiller/

Turnquest, A. (2014b, September). Religious texts often used to argue against gender inequality. The Tribune. Retrieved from http://www.tribune242.com/news/2014/sep/02 /religious-texts-often-used-argue-againstgender-in/

Turnquest, A. (2018a, October). Who's in charge? Mostly women, apparently. The Tribune. Retrieved from http://www.tribune242.com/news/2018/oct/26/ whos-charge-mostly-women-apparently/

Turnquest, A. (2018b, March). Churches propose marriage controls. The Tribune. Retrieved from http://www.tribune242.com/news/2018/mar/07 /churches-propose-marriage-controls/

United Nations Human Rights, Office of the High Commissioner. (2017, December). The Bahamas: UN Special Rapporteur calls for fresh steps to tackle violence against women.
Retrieved from http://www.ohchr.org/EN/NewsEvents/Pages/ DisplayNews.aspx ?NewsID $=22554 \&$ LangID $=$ E

Vanderbilt University. (2014). Latin America Public Opinion Project: The Bahamas. Retrieved from http://www.vanderbilt.edu/lapop/bahamas.php

Wells, R. (2019, June 6). Davis: PLP to have "30 to 40 percent" women candidates. The Tribune. Retrieved from http://www.tribune242.com/news/2019/jun/07/ davis-plp-have-30-40-percent-womencandidates/

Wood, H. J. (2019). Gender inequality: The problem of harmful, patriarchal, traditional and cultural gender practices in the church. HTS Teologiese Studies/Theological Studies, 75(1), a5177. https://doi.org/10.4102/hts.v75i1.5177

World Health Organization. (2017). Violence against women. Retrieved from http://www.who.int/en/news-room/factsheets/detail/violence-against-women 